\title{
GIBBON WAS RIGHT: \\ THE DECLINE AND FALL OF THE ROMAN ECONOMY*
}

\author{
WiLlem M. Jongman
}

\section{Roman economic history as world history}

Why did the Roman Empire fall? For centuries the question has excited many people, and rightly so. In recent decades, however, the question seems to have lost its legitimacy. Instead, in the work of some of the finest Roman historians of our time the very notion of decline and fall has been replaced by that of transformation: 'the Roman Empire did not fall, it just transformed into something different.'

It was the genius of Peter Brown above all who showed us the continued vitality and originality of late antique culture, and who taught us the inadequacy of traditional chronologies. ${ }^{1}$ It was a revisionism that fitted perfectly with the cultural and political criticism of the nineteen sixties and after. It questioned the validity and centrality of one of the cultural icons of western civilization: the classical period of classical antiquity. Thus, it was part of a larger revisionism that also included a bigger role for the history of the Roman provinces, or the histories of women and slaves. As economic history it also fitted perfectly with the emerging structural economic history of the longue durée, where change was only superficial, and where the fundamental characteristics of the economic system remained forever the same. Finally, it fitted perfectly with a Finleyan pessimism that treated all of ancient economic history as one static system that never saw any real progress in technology or standard of living. ${ }^{2}$ If the ancient economy had never been much of a success, it could not have declined dramatically either.

* I should like to thank François de Catalaÿ and JRA for permission to publish graphs 1 and 2, Burghart Schmidt for graphs 3 and 4, and Cambridge University Press for my graphs 5 and 6.

${ }^{1}$ P.R.L. Brown, The world of late antiquity: from Marcus Aurelius to Muhammed (London $1971)$ is seminal.

${ }^{2}$ M.I. Finley, The ancient economy (London 1973). 
Here, I want to present an alternative and more dynamic account. ${ }^{3}$ Inevitably the perspective of the rise of the modern economy looms large over any account of economic change. We live in a world of rapid economic growth such as the world has never seen before. Over a period of one or two centuries human life has changed beyond recognition. On average we live some three times longer than our ancestors, there are vastly more of us, and we are far more prosperous. The transition, moreover, has come about over a period of less than a century. Since then, we are on a voyage of no-return into what may well be environmental oblivion. The question how this (and the concomitant cultural and political changes) could have come about is quite obviously the most important question any historian could ask. A common answer is that the rise of the modern economy is the product of a long, slow, and uniquely European process of historical change predisposing the European economy for the rapid change that was to come with the Industrial Revolution. For an ultimate explanation for this success of the modern western economy many historians have looked to the rise of the medieval commercial bourgeoisie and the cultural, social and economic changes that went with it. ${ }^{4}$ From then on, history moved in only one direction, and that was up. Ancient historians have largely concurred with this medievalist Annales paradigm, and focused on why the modern world did not begin even earlier. Antiquity thus became a primitive precursor of the medieval world. In this model too the trend is upwards, but from an even lower starting point.

Unknown to many ancient historians, however, a new paradigm for the rise of the modern economy has emerged emphasizing the essential discontinuity of the rise of the modern world. ${ }^{5}$ Thus, in this view the Industrial Revolution is once again industrial and revolutionary, and the rise of modernity owes little to centuries long past. In a related argument, world historians such as Ken Pomeranz have argued that on the eve of the Industrial Revolution China, for example, was at least

${ }^{3}$ G.f. W.M. Jongman, 'Slavery and the growth of Rome. The transformation of Italy in the first and second century B.C.E.', in C. Edwards and G. Woolf (eds.), Rome the Cosmopolis (Cambridge 2003), 100-122.

${ }^{4}$ W.M. Jongman, The Economy and society of Pompeii (Amsterdam 1988) chapter 1 for extended comparative discussion.

${ }^{5}$ E.A. Wrigley, Continuity, Chance and Change. The Character of the Industrial Revolution in England (Cambridge 1988). 
as advanced as Europe, if not more so. ${ }^{6}$ Europe's success, therefore, cannot be explained by centuries of slow economic and social change predisposing it for the part it was to play later. The model of the upward millennial trend has thus been discredited, and ancient historians would do well to abandon their search for reasons why modernity did not rise in antiquity.

So what are we left with for pre-industrial history? Was it all one longue durée of life at or near subsistence? The answer is that it was not. Pre-industrial per capita incomes could be quite different between regions and periods, from near-subsistence to about three times subsistence (anything better had to wait until after the Industrial Revolution). ${ }^{7}$ The classic explanation for the differences is in the land-labour ratio. ${ }^{8}$ When population increased, more and more people had to work smaller and smaller plots of land. This intensive cultivation improved the productivity of the land, but at the expense of labour productivity and, therefore, labour incomes. ${ }^{9}$ Thus, population and popular prosperity always moved in opposite directions. Periods of population pressure witnessed a declining standard of living for labour, increased rents and elite incomes, and therefore, greater social inequality. An epidemic such as the Black Death of the middle of the fourteenth century was a blessing in disguise for the survivors. This is the bleak Malthusian scenario, in which real economic growth does not exist: increased aggregate production under population pressure cannot qualify as real growth since it is at the expense of per capita incomes. Conversely, it would be equally perverse to think of improved per capita incomes in the wake of demographic decline as economic growth. To qualify as real economic growth, both population and per capita incomes (and thus even more so aggregate income) must move in the same direction, and for a lengthy period of time. Did this ever happen before the Industrial Revolution?

${ }^{6} \mathrm{~K}$. Pomeranz, The great divergence. China, Europe, and the making of the modern world economy (Princeton 2000); but see R.C. Allen, T. Bengtsson and M. Dribe (eds.), Living standards in the past: new perspectives on well-being in Asia and Europe (Oxford 2005) for critical data on a comparatively low Chinese standard of living.

7 Allen, Bengtsson and Dribe 2005, op. cit. (n. 6) for a recent survey.

${ }^{8}$ Jongman 1988, op. cit. (n. 4), 85-91 for discussion, and an application to ancient history.

${ }_{9}$ Ancient historians often confuse labour productivity, productivity of the land, and total factor productivity. 


\section{Roman economic growth and decline}

It is my contention that Rome in the late Republic and early Empire was one of those rare examples of real pre-industrial economic growth (others would be the Dutch Republic and England in the centuries just before the Industrial Revolution). The last one or two centuries B.C. and the first one or two centuries A.D. witnessed the rise of the first and at the time largest world-empire of human history. ${ }^{10}$ That Empire, moreover, was not only large, but also populous. Even if much of Rome's demographic history will escape us forever, I think there is scholarly consensus that population density in the Roman Empire was not only high, but that population pressure was highest in the first and early second centuries A.D. What I want to argue, however, is that contrary to what one would expect the population pressure of the late Republic and early Empire did not only increase aggregate production and consumption, but that there were also clear improvements in per capita production and consumption: there was some real prosperity growth. ${ }^{11}$ Thus, Roman material culture of the early Empire was unprecedented, and would remain unsurpassed for many centuries (until, perhaps, a century ago). Our Renaissance ancestors were quite right to be amazed when they saw, for example, the ruins of an ancient city of Rome that once held a million people. It had indeed been a city of marble: in two centuries the Romans quarried more marble than has been quarried in the world since antiquity. ${ }^{12}$ Rome and the other cities of the empire had a spectacular built environment such as the world would not see for a long time to come, with public baths, aqueducts, arenas, temples, paved roads, drains, and splendid elite housing.

However, Roman grandeur had been more than brick and marble, and included a new prosperity for many if not all. From the late fourth and early third century B.C. increased urban demand for food had stimulated the growth of larger farms and the production of market

${ }^{10}$ W.M. Jongman, 'The Roman economy: from cities to empire', in L. de Blois and J. Rich (eds.), The transformation of economic life under the Roman Empire. Impact of Empire 2 (Amsterdam 2002), 28-47.

${ }_{11}$ W.M. Jongman, 'The early Roman Empire: consumption', in R.P. Saller, I. Morris and W. Scheidel (eds.), The Cambridge economic history of the Greco-Roman world (Cambridge 2007), 592-618.

${ }^{12}$ J.C. Fant, 'Ideology, gift and trade: a distribution model for the Roman imperial marbles', in W.V. Harris, The Inscribed Economy (Ann Arbor 1993), 145-170; P.F.B. Jongste, Het Gebruik van Marmer in de Romeinse Samenleving (Leiden 1995). 
crops. A network of Roman roads both large and small had begun to integrate urban and rural economies. ${ }^{13}$ This new wealth was not just the wealth of a small elite (although the elite did indeed grow significantly richer), but reached an increasingly prosperous subelite, and significant sections of the working population. The cities of the late Republic and early Empire were magnets drawing immigrants into an expanding urban economy of manufacturing and extravagant public and domestic service. ${ }^{14}$

Thus, Rome's economic achievement was great enough for decline to be potentially dramatic. And indeed a few centuries later in many parts of the Empire (though probably not in all) much of the grandeur was gone. Population had declined, sometimes dramatically, cities were much smaller, interregional trade had declined, industrial and agricultural production were less than before, and for many standard of living was much lower than before. There was indeed decline before the fall.

\section{Evidence}

Before we turn to possible explanations, I want to present some evidence - both old and new - of this dramatic contrast between early imperial prosperity and subsequent decline. Roman wages are badly known, but even so for the early imperial period they seem to have been well above subsistence. ${ }^{15}$ The high cost of wage labour is mirrored in high and rising prices of slaves (theoretically, high slave prices imply wages that were well above subsistence). ${ }^{16}$ During the late Republic, and precisely during the period of increasing slave supplies, slave prices rose perhaps two-fold. ${ }^{17}$ The growth of slavery in the face of rising slave prices shows that it was demand driven and probably reflected a higher cost of wage labour.

Most other data are archaeological, however, and I do indeed believe that it is only archaeology that can provide the large datasets that we need as empirical foundation for a time series analysis of long term

\footnotetext{
${ }_{13}$ R.Laurence, The roads of Roman Italy: mobility and cultural change (London 1999).

14 Jongman 2003, op. cit. (n. 3), 100-122.

15 Jongman 2007, op. cit. (n. 11), 592-618; 600-602.

16 For the logic: E. Domar, 'The causes of slavery or serfdom: a hypothesis', Economic History Review 30.1 (1970), 18-32.

17 K. Hopkins, Conquerors and Slaves (Cambridge 1978), 161 and 167; Jongman 2007, op. cit. (n. 11), 601-602.
} 
economic change in antiquity. I appreciate that some of these datasets may be and have been criticized singly, but I also believe that the independent repetition of the same pattern in a large number of separate archaeological datasets argues firmly against too much scepticism.

The first graph to ever show the dramatic picture of late Republican and early imperial growth, and subsequent decline, was the now famous graph Keith Hopkins published from Parker's catalogue of Roman shipwrecks. ${ }^{18}$ As Hopkins observed, for a few centuries, long distance maritime trade (as measured by dated shipwrecks) was larger than ever before, but also larger than it would be for many centuries to come.

As François de Calataÿ recently argued, this dramatic rise and subsequent decline of dated Roman shipwrecks was part of a larger pattern. ${ }^{19}$ Ice cores from Greenland show late Republican and early Imperial

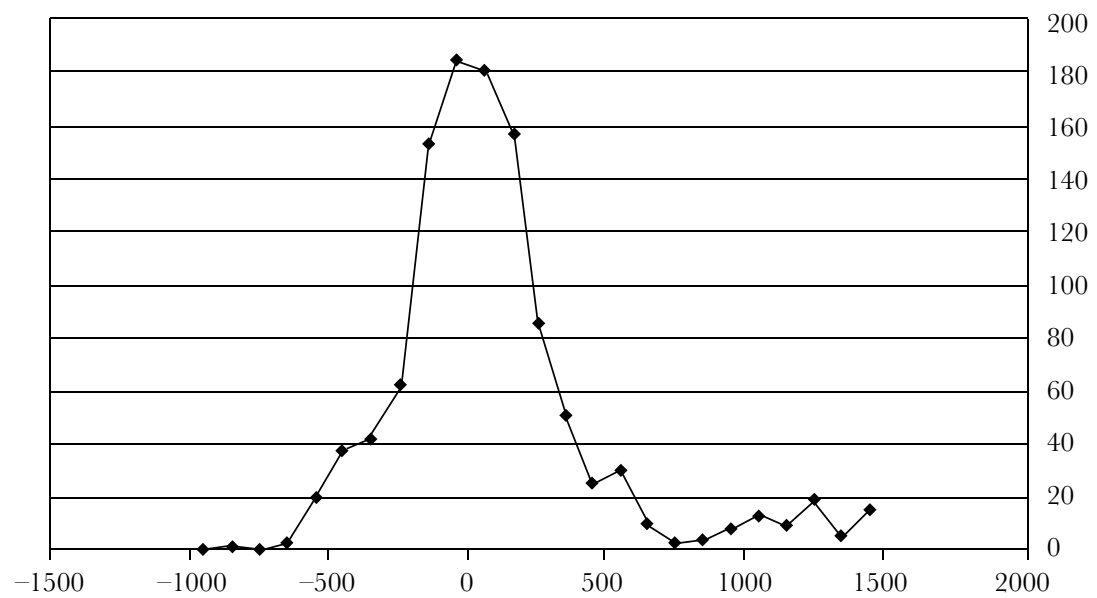

Graph 1: dated shipwrecks (from De Catalä̈ 2005)

${ }^{18}$ K. Hopkins, 'Taxes and trade in the Roman Empire (200 B.C.-A.D. 400)', fournal of Roman Studies 70 (1980), 101-125, especially 105-106 based on data from Parker's subsequently published catalogue: A.J. Parker, Ancient shiprerecks of the Mediterranean and the Roman provinces (Oxford 1992), 580. See F. de Calataÿ, 'The Greco-Roman economy in the super long run: lead, copper and shipwrecks', Fournal of Roman Archaeology 18 (2005), 361-372; K. Hopkins, 'Rome, taxes, rents and trade', in W. Scheidel and S. von Reden (eds.), The ancient economy (Edinburg 2002), 190-230 for a later version of the argument.

${ }^{19}$ De Calataÿ 2005, op. cit. (n. 18). 
levels of atmospheric metal pollution that testify to a spectacular peak in metal extraction during the period. Money supply could thus increase dramatically during the second and first century B.C. ${ }^{20}$ In the early Roman Empire monetary stock was proportionally even larger than in any period of European pre-industrial history. ${ }^{21}$

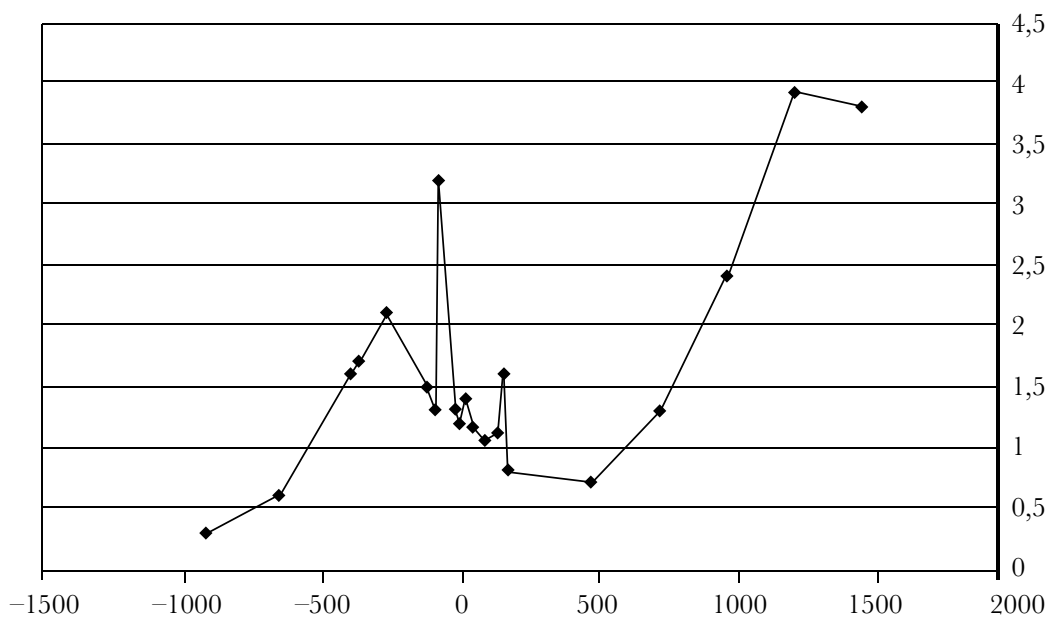

Graph 2: Lead pollution in Greenland ice cores ${ }^{22}$

Other datasets show a similar pattern. For example, the chronology of (very precisely) dated wood remains from western and southern Germany shows a pattern of building activity with (after an early imperial peak) a steep decline from the late second century A.D., and a partial late antique and early medieval recovery. ${ }^{23}$

20 Hopkins 1980, op. cit. (n. 18).

21 W.M. Jongman, 'A golden age. Death, money supply and social succession in the Roman Empire' in E. Lo Cascio (ed.), Credito e moneta nel mondo romano (Bari 2003), 181-96.

22 De Calatä̈ 2005, op. cit. (n. 18), 370.

23 B. Schmidt and W. Gruhle, 'Klimaextreme in Römischen Zeit - Ein Strukturanalyse dendrochronologischer Daten', Archäologisches Korrespondenzblatt 33 (2003) 421-427, graphs at 422 . 


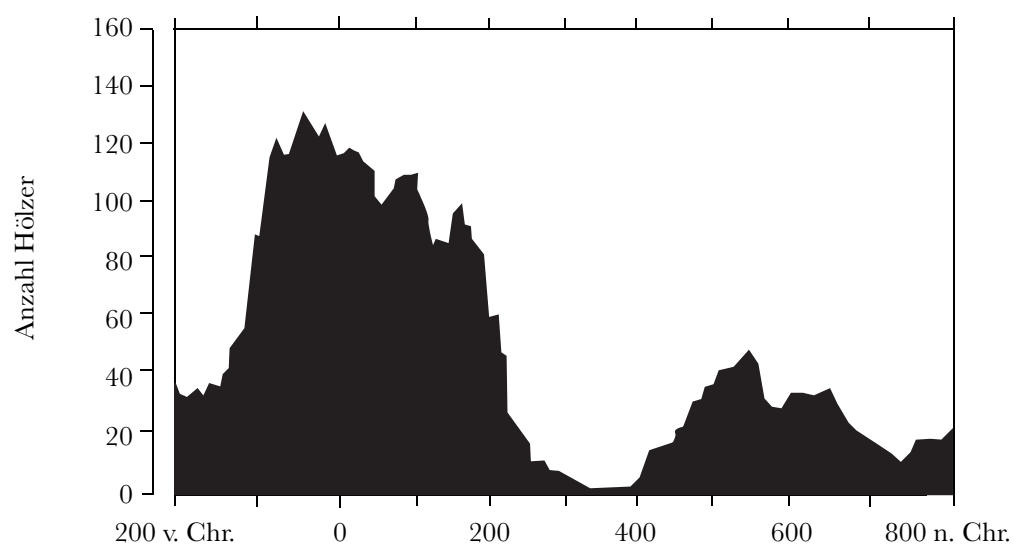

Graph 3: dated wood remains from western Germany (Trier laboratory)

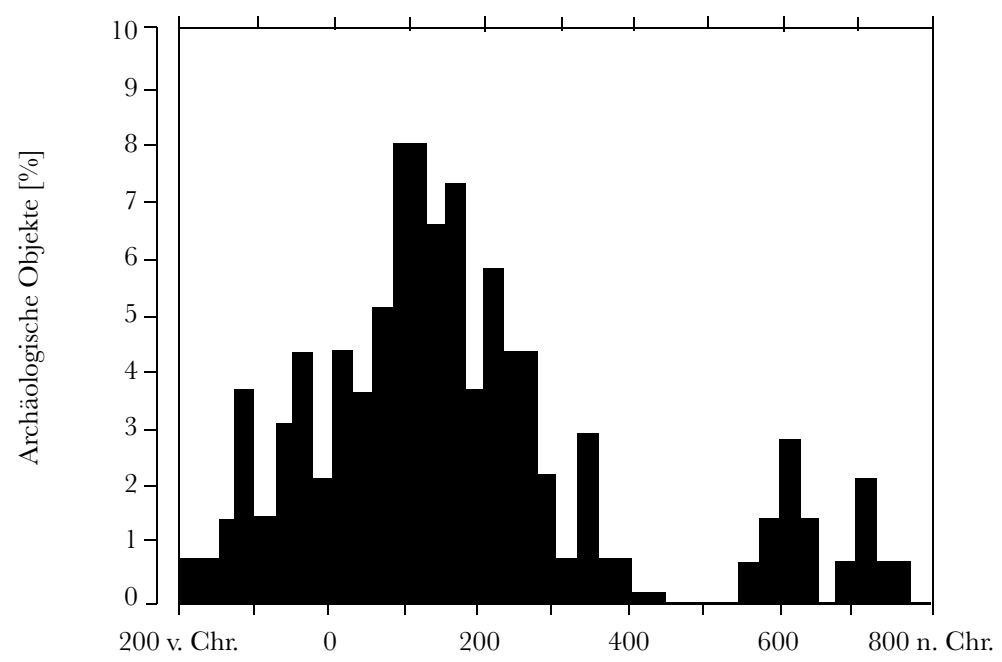

Graph 4: archaeological finds in western Germany (Trier laboratory)

Similarly we may look at Hollstein's chronology of archaeological finds in western Germany. It shows a marked peak under the Principate, but a steep decline thereafter. ${ }^{24}$

24 E. Holstein, Mitteleuropäische Eichenchronologie (Mainz 1980), 137. 
The late Republican and early Imperial peak for such aggregate variables is perhaps not surprising. What is surprising is the extent of that growth: shipping, metal extraction, or building had obviously increased by much more than could be expected from just population growth. Similarly, decline was much steeper than could be expected from just demographic contraction. This confirms the story of the wage data and slave prices: per capita incomes did not decline under population pressure. On the contrary, I think we can see an improved standard of living, and, therefore, a measure of real economic growth in the face of a rising population. This new wealth was also, I now believe, shared more widely than earlier pessimistic critics of Roman society such as myself were willing to acknowledge. Equally, however, the demographic contraction from the late second century A.D. did not improve standard of living - on the contrary.

Diet is another obvious indicator of standard of living. The Roman conquest of North Western Europe heralded an increasing consumption in that part of the world of a wide range of new fruits and vegetables..$^{25}$ However, after the richness of the early imperial diet, the range of fruits and vegetables available in the northwestern provinces decreased again in later antiquity. This same pattern is repeated with domestic animals. For a while, pigs, cows, sheep or horses, and even chicken, were much larger than ever before, and for a long time after. ${ }^{26}$ Moreover, domestic animals not only had far more meat on them, but also many more of them were eaten: the chronological distribution of animal bone assemblages shows rapid increases of meat consumption in Italy from the third century B.C. onwards (graph 5), and from the first century B.C. in the provinces (graph 6). ${ }^{27}$

I take these graphs to represent meat consumption. The chronological distribution of Roman animal bone assemblages follows a pattern that is remarkably similar to other chronological distributions of Roman economic activity. With the growth of the Roman Empire, larger parts of the population had become prosperous enough to improve their diet with meat. That is important because more than quantity,

${ }^{25}$ C.C. Bakels and S. Jacomet, 'Access to luxury foods in Central Europe during the Roman period', World Archaeology 34 (2003), 542-557.

${ }^{26}$ G. Kron, 'Archaeozoology and the productivity of Roman livestock farming', Münstersche Beiträge zur antiken Handelsgeschichte 21.2 (2002), 53-73.

27 Jongman 2007, op. cit. (n. 11), 613-614, based on data in A. King, 'Diet in the Roman world: a regional inter-site comparison of the mammal bones', fournal of Roman Archaeology 12 (1999), 168-202, and his earlier data collections referred to there. 


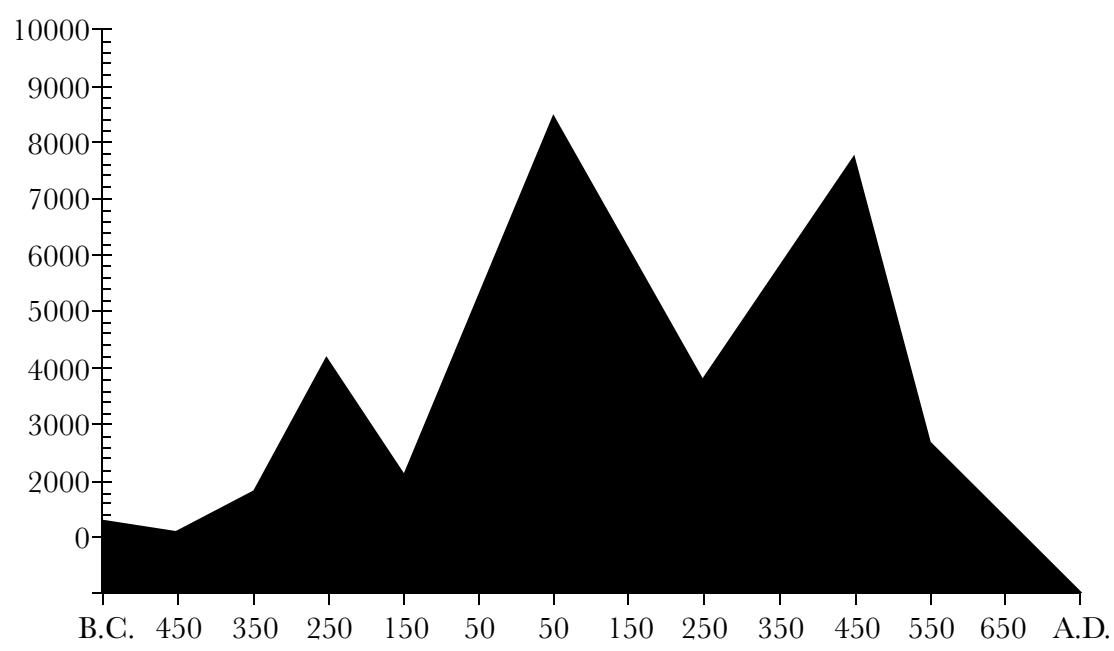

Graph 5: Animal bone assemblages in Roman Italy (bones deposited per century)

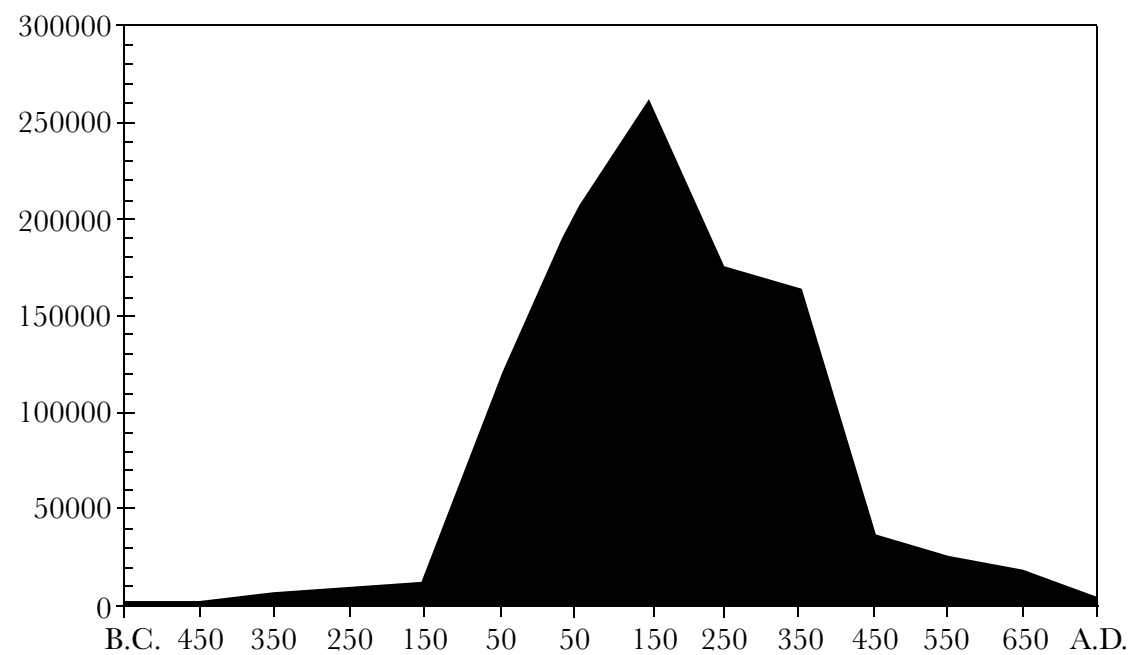

Graph 6: Animal bone assemblages in the provinces of the Roman Empire (bones deposited per century) 
it is the quality of the diet that shows improvements in the standard of living. Meat was expensive food, but also tasty and healthy. The income elasticity of demand for meat was high: the very poor could not afford meat, but even moderately higher incomes lead to a substantially increased demand for meat. Conversely, the very rich would not eat more meat than those who were just plain rich. Thus, as an indicator, meat consumption is sensitive precisely where one most wants such sensitivity. Unfortunately, and as with other signs of prosperity during the early Roman Empire, these benefits did not last: the subsequent decline was as steep as the growth, even if it is muted in the graph by uncertainties about the precise dating of some sites. For many of these datasets a higher chronological resolution is both desirable and possible. I would expect to find a steeper and more clearly dated decline, once imprecisely dated observations are removed (to do that is one of my research priorities for the next few years).$^{28}$ Further advances are also possible when we subdivide datasets (provided they are large enough). As an example, animal bone deposition in Roman Italy shows a distinct pattern that should interest the historian: the third century A.D. shows a dramatic decline, but recovery thereafter was marked until the final late antique demise.

Meat also confers real health benefits. Perhaps as a result, Romans also became taller: under the Principate Romans became about the tallest, and presumably most prosperous, pre-industrial Europeans. ${ }^{29}$ When people are well-fed and healthy they grow taller than those who are undernourished and disease ridden. Modern economic historians such as Robert Fogel have successfully used stature data to reconstruct the modern rise in the standard of living. ${ }^{30}$ For earlier times, the approach

\footnotetext{
${ }^{28}$ Chronology matters, and too often I am frustrated by the presentation of grouped data, with, for example, historically uselessly large periods such as 'first and second century A.D.' and 'third and fourth century A.D.' With a bit of effort, these published archaeological time series can be made much more precise, and that is one of the things I intend to do. An example is in the shipwreck graph as originally published by Hopkins. He had time periods of two centuries, and as a result the rise and decline seemed quite slow. In François de Calataÿ's recent version, the time periods are shorter, and we can now see that decline set in earlier.

${ }^{29}$ G.M. Klein Goldewijk and W.M. Jongman, 'They never had it so good. Roman stature and the biological standard of living', forthcoming.

${ }^{30}$ R.W. Fogel, The escape from hunger and premature death, 1700-2100: Europe, America and the Third World. (Cambridge 2004); J. Komloss (ed.), Stature, living standards, and economic development: essays in anthropometric history (Chicago 1994); R. Steckel and J. Rose (eds.), The Backbone of History. A History of Health and Nutrition in the Western Hemisphere (Cambridge and New York) 2002.
} 
needs skeletal data. For a variety of reasons previous research failed to crack these data properly, and recover any patterns. ${ }^{31}$ A combination of better archaeology and physical anthropology on the one hand, and statistical simplicity on the other hand shows what had escaped until now.

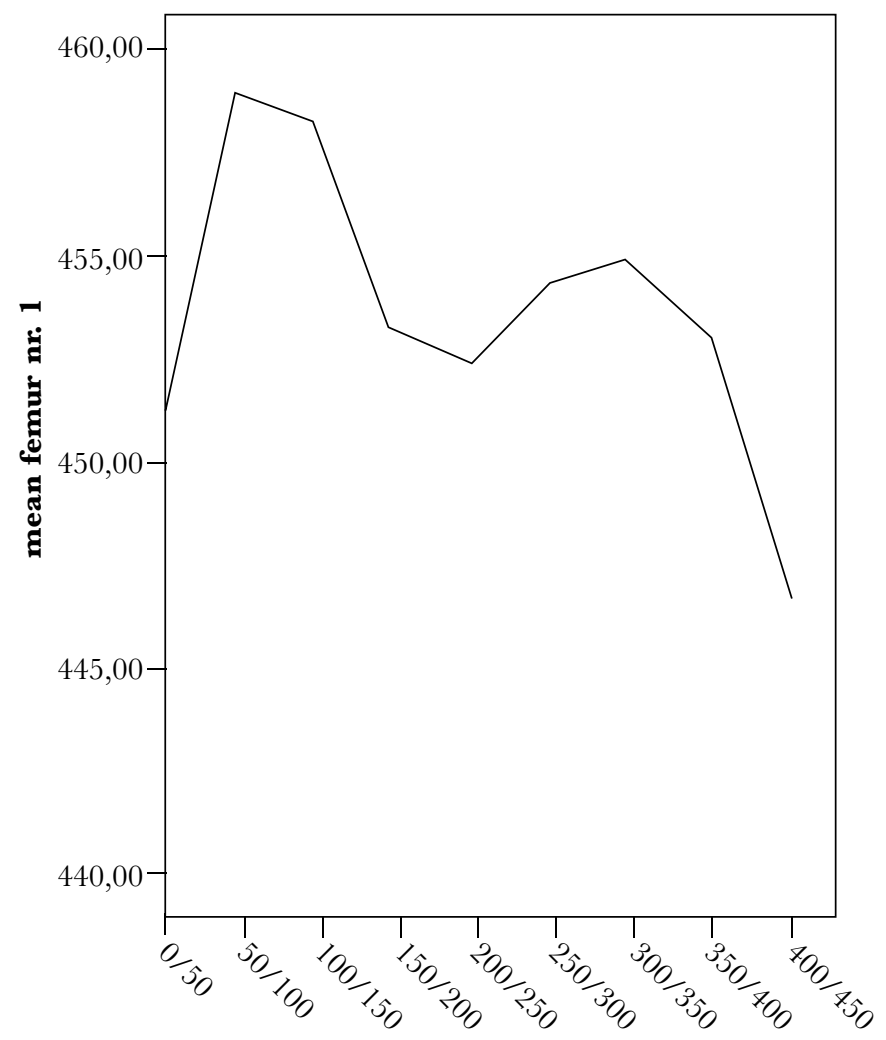

\section{birth year cohort}

Graph 7: the history of Roman femur length ${ }^{32}$

${ }^{31}$ N. Koepke and J. Baten, 'The biological standard of living in Europe during the last two millennia', European Review of Economic History 9 (2005), 61-95; G. Kron, 'Anthropometry, physical anthropology and the reconstruction of ancient health, nutrition and living standards', Historia 56 (2005), 68-83. The biggest problem was the use of total body length as core variable when that total body length is often only a reconstruction from measurements of no more than a few long bones, and of the femur in particular.

${ }_{32}$ From Klein Goldewijk and Jongman forthcoming, op. cit. (n. 29). 
Again, the rise is spectacular - the first and early second century peak equates European stature in the early twentieth century. Decline clearly set in in the late second century A.D., to be followed by a recovery later in the third century, and ultimate collapse with the fall of the Western Empire. As with the animal bone data, the late antique recovery is due to Mediterranean sites in our sample. In North Western Europe, the biological standard of living did not recover from the late second century shock.

\section{The rupture}

The precise chronology of these data is interesting, in that decline seems to have set in sometime in the late second century. An obvious candidate for an explanation would be the Antonine Plague that cursed the Roman world from precisely the mid 160's. ${ }^{33}$ Of course, some have expressed reservations about the impact of the Antonine Plague, but I really think too many datasets show remarkable disruptions in the late second century. It is evident that the same pattern occurs in far more data series than those originally published by Duncan-Jones.

At the same time, as John Nicols has argued so persuasively in his paper for this volume, climate change may also have a part in this story. From about the late second century A.D., and after a few centuries of remarkably warm and humid weather, Rome was entering a period of cooler and dryer weather that was to last a few centuries.

It is too early for an assessment of the relative impact of these two changes. ${ }^{34}$ We know the Antonine Plague occurred, and we know it recurred. What we do not know is how severe the demographic effect was - although I think we have highly suggestive evidence that it was substantial..$^{35}$ As for empire-wide climate change, the change itself may be more controversial, but few would deny that such climate change

${ }^{33}$ R.P. Duncan-Jones, 'The impact of the Antonine plague', Fournal of Roman Archaeology 9 (1996), 108-136 is fundamental.

34 Analytically, the plague or climate change would have worked out somewhat differently. Both would have entailed changes in the land-labour ratio, and thus movement along the production function. Climate change would also have implied shifts off the production function itself (i.e. a negative technical change), because the same quantities of land and labour now produced less than before.

${ }_{35}$ Cf. C.P. Jones, "Ten dedications "to the gods and goddesses" and the Antonine Plague', fournal of Roman Archaeology 18 (2005), 293-301. 
could have hurt the Roman economy ${ }^{36}$ If, as I believe, there was indeed epidemic mortality, and if the climate did indeed deteriorate, we still do not know if these two external forces were independent from each other, or that climatic change had directly or indirectly changed the conditions for the outbreak of a major epidemic. Again, precise chronology may well provide the vital clues, or subdivisions of datasets to show regional variations. Both explanations are also strategically attractive because they are probably and perhaps largely (disease), or even certainly and completely (climate) exogenous to the economic system.

\section{Responses}

For the naive historian, it would seem that we now have all we need: we have a range of examples of catastrophic decline, and some potential causes. What we do not yet have, however, are the mechanisms by which this shock propagated through the economic and social system. Imagine a pre-industrial and largely agricultural economy in a fairly stable equilibrium. Next that equilibrium is disturbed by catastrophic mortality: what do we expect to happen when the proportion between people and assets changes? On the monetary side, we would expect to see sudden and pretty rampant inflation. The monetary stock remains the same for the time being, and the velocity of circulation probably does not change either. What changes is the number of transactions, for the simple reason that at the very least there are far fewer people to perform these transactions. Monetary theory predicts that inevitably, therefore, prices will rise in proportion. As others have argued, that is precisely what Egyptian data seem to suggest: prices and wages rose quite dramatically in the wake of the Antonine Plague. ${ }^{37}$ As every monetary historian knows, something else began to change as well: the coinage itself began its slide into substantial debasement. Theoretically, there was no need for that. The money stock was large, and by now even too large. The best policy would have been for the state to reduce

\footnotetext{
${ }^{36}$ J. Haas, Die Umweltkrise des 3. Fahrhundert n. Chr. im Nordwesten des Imperium Romanum: interdisziplinäre Studien zu einem Aspekt der allgemeinen Reichskrise im Bereich der beiden Germaniae sowie der Belgica und der Raetia (Stuttgart 2006) for caution.

${ }^{37}$ D. Rathbone, 'Prices and price formation in Roman Egypt', in J. Andreau, P. Briant and R. Descat (eds.), Prix et formation des prix dans les économies antiques (SaintBertrand-de-Comminges 1997), 183-244. Empirically, the jury is still out on whether wages rose more than prices, or vice versa.
} 
the money supply, by either taking money out of circulation, or by raising the precious metal content of the coins, so that fewer coins could be made out of the same metal stock. That did not happen, and the reason must have been the needs of the state. It had become difficult to collect taxes in the turmoil of the day, precisely when the state also had to finance huge military efforts. The easiest way to pay for that effort was to strike more coins. Unfortunately, there are good indications that the combination of epidemic disaster and military unrest had badly affected the Spanish mines. They could not produce the silver for the coins that now had to be struck from fresh metal instead of collected as taxes. Debasement, therefore, was not the cause of inflation, but the consequence of inflationary pressures affecting state and society.

The biggest economic and social change, however, was to the landlabour ratio. Population went down. I think that was because of the Antonine Plague, but it does not matter if the cause was different. Since nobody argues that late second and third century population went up, we need to think what consequences we would expect when population declined. More land per person inevitably means a lower aggregate production: production per hectare must have gone down, since there was more land to work in the same amount of time. For this reason, and because some of the worst land was probably abandoned, production per man hour must have gone up, and thus also incomes from agricultural labour. Conversely, rents must have gone down, and therefore the incomes of elite land-owners. The Roman Empire should have turned into a world of happy and prosperous peasants, and much greater social equality than before. The theory is impeccable, but reality was, of course, different.

Duncan-Jones has recently surveyed the evidence for agricultural change, and concluded that there were two trends: the first is that from the third or even late second century A.D. site numbers declined pretty steeply in many (though not all) parts of the Empire. ${ }^{38}$ The second trend is that of a particularly steep decline of smaller sites, and an increase in the size of larger and sometimes even fortified sites. The agricultural decline seems to have gone together with a change in rural social relations.

38 R.P. Duncan-Jones, 'Economic change and the transition to late antiquity', in S. Swain and M. Edwards (eds.), Approaching late antiquity (Oxford 2004), 20-52. 
What we witness from the late second century is the emergence of a new social, political and legal regime, where oppression replaces the entitlements of citizenship. With the Constitutio Antoniniana of A.D. 212 virtually everyone was now a Roman citizen. The debasement of citizenship confirmed a trend that had started earlier in the second century with the emergence of a new social distinction between honestiores and humiliores. ${ }^{39}$ Status distinctions between free citizens and slaves were beginning to be blurred. Just as slaves had become more expensive in the late Republic, precisely when supplies had increased, now they seem to have become cheaper again (this process is much less well attested), even if supplies were less. As Moses Finley has argued, demand for slaves declined because citizens could now be exploited more fully. ${ }^{40}$ Theoretically, new market conditions for labour and land had created an improved bargaining position for labour and tenants. However, the land-owning elite countered this by the imposition of the non-economic force of oppression, as expressed in shifts in the laws of citizenship and status. At the crossroads of economic change, Rome debased the value of citizenship and followed the same route that Prussian Junkers were to follow during the so-called second serfdom. ${ }^{41}$ Roman patterns of land-holding seem to have changed with the growth of really large estates, and the decline of medium sized estates. As for agricultural labour, it may not be coincidence that the late second century is precisely the period of so many complaints from disgruntled tenants. ${ }^{42}$ The coloni of the Saltus Burunitanus of 180 were not alone to complain to the emperor about increased oppression and growing abuse. ${ }^{43}$ When pushed hard enough, they could have moved, but that was precisely what was to become illegal. Tied to the land, they lost their powers in the market. The argument is, therefore, that the declining legal status of citizens was not in itself a reflection of a declining economic position, but an instrument imposed in the face of what would have been an improved economic position for the peasantry if the market would have had its way.

\footnotetext{
${ }^{39}$ P.D.A. Garnsey, Social status and legal privilege in the Roman Empire (Oxford 1970).

${ }_{40}$ M.I. Finley, Ancient slavery and modern ideology (London 1980).

${ }_{41}$ R. Brenner, 'Agrarian class structure and economic development in pre-industrial Europe', Past and Present 70 (1976), 30-75.

42 P. Herrmann, Hilferufe aus römischen Provinzen: ein Aspekt der Krise des römischen Reiches im 3. Fhdt. n. Chr. (Hamburg 1990); T. Hauken, Petition and response: an epigraphic study of petitions to Roman emperors (Bergen 1998), 181-249.

${ }^{43}$ See CIL 8.10570 and 8.14464.
} 
This change in social relations is also reflected culturally. The late second century was a period of important cultural changes, for example in religion. Mithraism and perhaps a little later Christianity provided new forms of belonging and a sociability that no longer depended on civic life or patronal benevolence. ${ }^{44}$ Finally, government itself changed. For me, the interesting thing is the resilience of the Roman state. For more than half a century, the Severan regime maintained the integrity and continuity of the Roman state in the face of extraordinary pressures. The surprise is not that it finally collapsed, but that it survived and even flourished for so long that the crisis later became known as the crisis of the third century, rather than the crisis of the second century that I think it was.

Just as remarkable as the temporary Severan recovery is the recovery from Diocletian. Clearly, it not only inaugurated a new period of stability and more orderly succession, but it also generated a measure of economic recovery, in particular it would seem in Italy or the Mediterranean at large. The recovery was substantial enough for late antique economic decline to be dramatic.

The real beginnings of that decline and fall, however, may have been in the beginning of a period of much colder and dryer weather, and in the scourge of the Antonine Plague. With the growth of its Empire, with the growth of its cities, and with the growth of a system of government and transportation based on those cities, Rome had created the perhaps most prosperous and successful pre-industrial economy in history. The age of Antoninus Pius was indeed probably the best age to live in pre-industrial history.

Groningen, December 2006

University of Groningen

${ }^{44}$ R. Stark, The rise of Christianity: a sociologist reconsiders history (Princeton 1996); P.R.L. Brown, Poverty and Leadership in the Later Roman Empire (Hanover and London 2001). 